\title{
Effect of Methionine and Nitrous Oxide on Homocysteine Export and Remethylation in Fibroblasts from Cystathionine Synthase-Deficient, cb1G, and cb1E Patients
}

\author{
BENEDICTE CHRISTENSEN, DAVID S. ROSENBLATT, RICHARD C. CHU, AND \\ PER MAGNE UELAND \\ The Clinical Pharmacology Unit, Department of Pharmacology and Toxicology, University of Bergen, N-5021 \\ Haukeland Hospital, Norway [B.C., P.M.U.J, MRC Genetics Group, Centre for Human Genetics, McGill \\ University, Montreal, Quebec, Canada H3A IAI [D.S.R.], and Veterans Administration Medical Center,
} Albany, New York [R.C.C.]

\begin{abstract}
We investigated the nitrous oxide-induced inactivation of methionine synthase and the concurrent homocysteine (Hcy) export in mutant fibroblasts with defects in the homocysteine catabolizing enzyme, cystathionine $\beta$-synthase, or in methionine synthase, which carries out homocysteine remethylation. The fibroblasts were incubated in various concentrations of methionine to create conditions favoring methionine conservation or catabolism. In cystathionine $\beta$-synthase-deficient cells, high medium methionine partly protected the enzyme against inactivation, as previously found in normal fibroblasts. The Hcy export rate at low methionine levels was low $(0.2-0.6 \mathrm{nmol} /$ $\mathrm{h} / \mathbf{1 0}^{6}$ cells), and increased $2-3$-fold at high methionine levels. Nitrous oxide enhanced Hcy export rate at low methionine, so that in the presence of nitrous oxide, the Hcy export became less dependent of methionine. In cb1G cells, the enzyme inactivation was moderate and independent of medium methionine. The Hcy export rate was intermediate $\left(0.5-0.8 \mathrm{nmol} / \mathrm{h} / 10^{6}\right.$ cells) at low methionine levels, and increased moderately ( $<2$-fold) at high methionine levels or following nitrous oxide exposure. In cb1E mutants, the enzyme activity was not affected by nitrous oxide, and the Hcy export was high $\left(0.8-1.6 \mathrm{nmol} / \mathrm{h} / 10^{6}\right.$ cells) and independent of methionine and nitrous oxide. These data suggest that Hcy remethylation and cystathionine $\beta$ synthase activity are major determinants of Hcy export at low and high methionine, respectively. The low susceptibility of methionine synthase to nitrous oxide in the presence of high methionine or in cb1G or cb1E mutants is probably related to low catalytic turnover. (Pediatr Res 35: 3-9, 1994)
\end{abstract}

\section{Abbreviations}

Hcy, homocysteine (form not specified)

THF, tetrahydrofolate

5-methyl-THF, 5-methyltetrahydrofolate

Received March 9, 1993; accepted August 2, 1993.

Correspondence and reprints: Benedicte Christensen, M.D., Division of Pharmacology, Department of Clinical Biology, Armauer Hansens hus, 5021 Bergen, Norway.

Supported by grants from the Norwegian Cancer Society. B.C. is a Fellow of the Norwegian Cancer Society.
Intracellular Hcy is either salvaged to methionine through remethylation or is converted to cysteine via the transsulfuration pathway. In most cells, remethylation is catalyzed by methionine synthase (5-methyltetrahydrofolate-homocysteine methyltransferase, EC 2.1.1.13). This enzyme requires cobalamin as cofactor and 5-methyl-THF as methyl donor. The transsulfuration pathway directs superfluous Hcy to catabolism, and the first step is catalyzed by the vitamin $B_{6}$-dependent enzyme cystathionine $\beta$ synthase (EC 4.2.1.22) (1).

Hcy export into the extracellular medium represents a mechanism to reduce intracellular levels of Hcy under metabolic conditions resulting in Hcy accumulation. Cellular Hcy export is probably a determinant of the amount of Hcy in plasma (2). Plasma Hcy has received considerable medical attention, both because elevated level may cause vascular lesions leading to atherosclerosis $(3,4)$, and also because plasma Hcy is an indicator of deficiency or impaired function of cobalamin or folate (5) and of inborn errors of Hcy metabolism (6).

A number of inherited diseases are characterized by high levels of Hcy in plasma and massive excretion of Hcy. The most common form is cystathionine $\beta$-synthase deficiency (6). Rare forms affect Hcy remethylation, and among these defects, cblE and cblG complementation classes have impaired function of methionine synthase (7).

Patients with cystathionine $\beta$-synthase deficiency have elevated fasting plasma Hcy and abnormal Hcy response following oral intake of a standardized dose of methionine, i.e. methionine loading test (6). The cb1E and $\mathrm{cb} 1 \mathrm{G}$ mutations also cause elevated fasting Hcy in plasma (7). There is no report on methionine loading test in these patients, but normal response in cobalamindeficient patients and in one child with methylenetetrahydrofolate reductase deficiency (8) suggests that methionine synthase deficiency does not cause an abnormal response to a methionine loading test.

Clinical and experimental studies of methotrexate (9-11) and nitrous oxide $(12,13)$ have provided additional information on the role of methionine synthase as a determinant of cellular Hcy export. Methotrexate indirectly blocks methionine synthase by depleting reduced folates including 5-methyl-THF. This drug causes transient increase in plasma Hcy in patients $(9,10)$, and enhances Hcy export from cultured cells (11). Nitrous oxide, which oxidizes cobal(I)amin (14) and inactivates methionine synthase, has similar clinical (12) and experimental (13) effects.

In a recent experimental study (15), we measured Hcy export and methionine synthase activity in normal human fibroblasts cultured in the presence of increasing concentrations of methionine and with or without nitrous oxide. Varying methionine 
concentrations created conditions favoring methionine conservation or methionine excess, and mimicked the metabolic conditions obtained during fasting or a methionine loading test. The data obtained suggested that at low medium methionine, methionine synthase efficiently remethylates Hcy, and thereby reduces Hcy export. Furthermore, high methionine protected methionine synthase from inactivation by nitrous oxide, possibly by reduction of catalytic turnover through product inhibition (15).

In the present work we studied the functional state of methionine synthase in fibroblasts from cystathionine synthase deficient and $\mathrm{cblG}$ and cblE patients. We focused on the influence of this enzyme on cellular Hcy export, since this process is probably the basis for the high extracellular level of Hcy in these patients.

The sites of the enzyme defects in these cell lines are depicted in Fig. 1.

\section{MATERIALS AND METHODS}

Chemicals. L-Methionine, DL-homocysteine, $S$-adenosyl-Lmethionine, cyanocobalamin, folic acid, DL-5-methyltetrahydrofolate (barium salt), and dithioerythritol were obtained from Sigma Chemical Co. (St. Louis, MO). 2-Mercaptoethanol (pro analysis) and methanol (gradient grade) were from Merck, Darmstadt, Germany, and bis(3,5,5-trimethylhexyl)phthalate from Fluka Chemie, AG, Switzerland. $( \pm)-L-N^{5}-\left[\right.$ methyl $\left.-{ }^{14} \mathrm{C}\right] \mathrm{Methyl}-$ THF ( $54 \mathrm{mCi} / \mathrm{mmol}$; barium salt) was purchased from Amersham, Buckinghamshire, England. It was dissolved in $10 \mathrm{mM}$ ascorbic acid and stored as $200-\mu \mathrm{L}$ aliquots under nitrogen at $-80^{\circ} \mathrm{C}$ until use. Nitrous oxide, supplied as a mixture of $50 \%$ $\mathrm{N}_{2} \mathrm{O}, 25 \% \mathrm{~N}_{2}, 20 \% \mathrm{O}_{2}$, and $5 \% \mathrm{CO}_{2}$, and a mixture of $75 \% \mathrm{~N}_{2}$, $20 \% \mathrm{O}_{2}$, and $5 \% \mathrm{CO}_{2}$, referred to as air, were obtained from AGA AB Norgas, Oslo, Norway. Other reagents were obtained from sources given in a previous publication (15).

Cell lines and stock cultures. One human fibroblast cell line (referred to as CSD 751 cells) deficient in cystathionine $\beta$ synthase was isolated from a 19-y-old man with homocystinuria. Another cystathionine $\beta$-synthase-deficient fibroblast line (CSD 1374 cells) was from a 13-y-old female. Both lines (GM00751 and GM01374) were purchased from NIGMS Human Genetic Mutant Cell Repository, Coriell Institute for Medical Research, Camden, NJ.

Three cb1E mutant fibroblast lines (WG 788, WG 1384, and WG 1575) were obtained from the Repository for Mutant $\mathrm{Hu}$ -

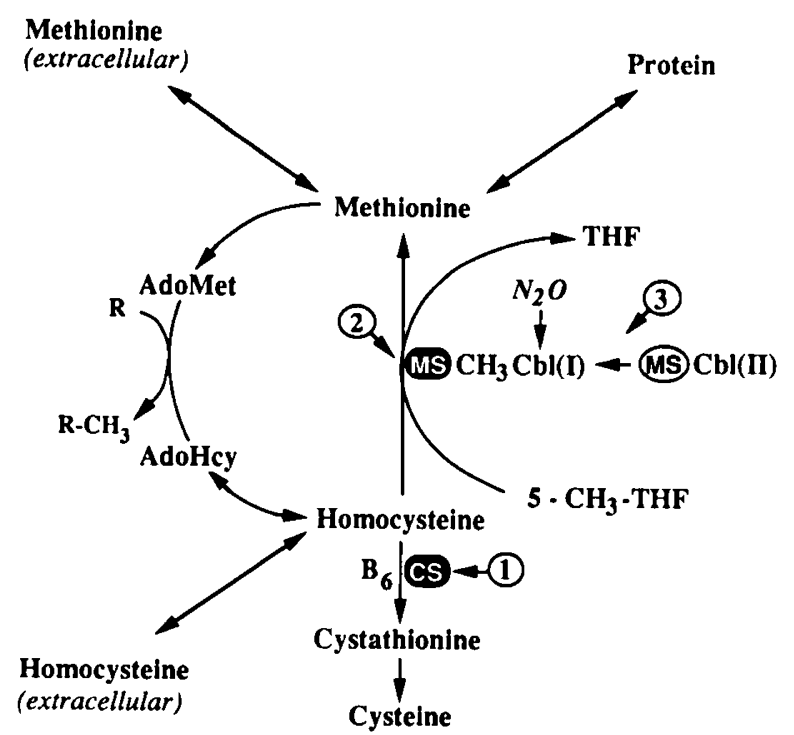

Fig. 1. Hcy, methionine, and cobalamin metabolism and the sites of defects in the mutant fibroblasts. MS, methionine synthase; CS, cystathionine $\beta$-synthase; 1 , cystathionine $\beta$-synthase deficiency; 2 , cb1G mutation; 3, cblE mutation. man Cell Strains, Montreal Children's Hospital. One cell line (referred to as cblE 788) was isolated from a 3-mo-old boy (16), another (cb1E 1384) from a 9-y-old boy, and the third (cb1E 1575) from a 1-y-old boy. All infants had cb1E disease.

Three cb1G mutant cell lines (GTA, WG1308, and WG2009) were investigated. GTA (referred to as cblG TA) was isolated from a 5-mo-old boy and was obtained by Dr. C. A. Hall, Veterans Administration Medical Center, Albany, NY. WG 1308 (cblG 1308) was from a 2-mo-old boy and WG 2009 (cblG 2009) from a 39-y-old man.

Stock cultures of all cell lines were grown in Dulbecco's modification of Eagle's medium (Flow Laboratories, Irvine, Scotland) containing $200 \mu \mathrm{mol} / \mathrm{L}$ L-methionine, $2.3 \mu \mathrm{mol} / \mathrm{L}$ folic acid, $1.5 \mu \mathrm{mol} / \mathrm{L}$ cyanocobalamin, and supplemented with nonessential amino acids $(3.6 \mathrm{mmol} / \mathrm{L} \mathrm{each})$ and $10 \%$ heat-inactivated fetal calf serum.

Cell culture conditions. All experiments were performed with cells transferred to and cultured in variants of the RPMI 1640 medium (Flow Laboratories), to allow comparison with previous studies $(13,15)$. The fibroblasts were grown in $50 \mathrm{~mL}\left(25 \mathrm{~cm}^{2}\right)$ tissue culture flasks (Nunc, Roskilde, Denmark) with $5 \mathrm{~mL}$ of medium and in an atmosphere of $5 \% \mathrm{CO}_{2} / 95 \%$ air at $37^{\circ} \mathrm{C}$. The relative humidity was $98 \%$.

Nitrous oxide exposure, methionine loading, harvesting of $\mathrm{cul}$ tured cells. To create optimal conditions for the assessment of enzyme inactivation and Hcy export, respectively, the experiments were conducted both at high (mid- to late logarithmic growth phase) and low cell density.

Cells were grown to mid- to late logarithmic growth phase in the presence of $30 \mu \mathrm{mol} / \mathrm{L}$ methionine until they reached $>0.3$. $10^{5}$ cells $/ \mathrm{mL}$. Then the medium was replaced with fresh medium containing $15,30,150$, and $1000 \mu \mathrm{mol} / \mathrm{L}$ methionine, and the culture flasks carefully flushed for $1 \mathrm{~min}$ with either $50 \%$ nitrous oxide or air (control) delivered at a rate of $2 \mathrm{~L} / \mathrm{min}$ via a sterile pasteur pipette. The cells were harvested after $1.5,3,6,12,24$, 36 , or $48 \mathrm{~h}$ of gas exposure.

The Hcy export rate is dependent on cell density and decreases when growth reaches confluence (17). Therefore, we also performed experiments with cells seeded at lower density. When the cells reached a density of $1-5 \cdot 10^{4}$ cells $/ \mathrm{mL}$ (about $48 \mathrm{~h}$ after seeding), the medium was replaced with fresh medium containing $15,30,150$, and $1000 \mu \mathrm{mol} / \mathrm{L}$ methionine and exposed to air or nitrous oxide, as described above. The cells were harvested at intervals of $24 \mathrm{~h}$ for $1 \mathrm{wk}$.

Biochemical analyses. The intact cell assay for methionine synthesis is based on the incorporation of ${ }^{14} \mathrm{C}$ from $5-[$ methyl${ }^{14} \mathrm{C}$ ]methyl-THF into proteins of cells incubated for $18 \mathrm{~h}$ in a medium containing $0.2 \mathrm{mmol} / \mathrm{L} \mathrm{L}-\mathrm{Hcy}$ thiolactone and $5 \mu \mathrm{mol} /$ L 5-[methyl $\left.-{ }^{14} \mathrm{C}\right]$ methyl-THF, but lacking methionine and folic acid. Details of the assay have been published (15).

Determination of methionine synthase activity was performed by a modification of the radioisotope assay described by Weissbach et al. (18). After thawing, the cell pellet was homogenized in $200 \mu \mathrm{L}$ of $50 \mathrm{mmol} / \mathrm{L}$ potassium phosphate buffer, pH 7.4, containing $100 \mathrm{mmol} / \mathrm{L} \mathrm{NaCl}, 10 \mathrm{mmol} / \mathrm{L}$ dithioerythritol, and $0.05 \%$ Triton $\mathrm{X}-100$. The incubation mixture (final volume of $100 \mu \mathrm{L}$ in $0.6-\mathrm{mL}$ polyethylene tubes) contained $400 \mu \mathrm{mol} / \mathrm{L}$ DL-homocysteine, $500 \mu \mathrm{mol} / \mathrm{L}( \pm)-5-\left[\right.$ methyl $\left.-{ }^{14} \mathrm{C}\right] \mathrm{methyl}-\mathrm{THF}(2$ $\mu \mathrm{Ci} / \mu \mathrm{mol}), 50 \mu \mathrm{mol} / \mathrm{L}$ cyanocobalamin, $300 \mu \mathrm{mol} / \mathrm{L} S$-adenosyl-L-methionine, $125 \mathrm{mmol} / \mathrm{L}$ 2-mercaptoethanol, $50 \mathrm{mmol} / \mathrm{L}$

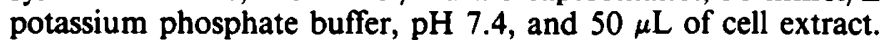
The incubation was started by addition of the extract, and the incubation mixture was overlayered with $50 \mu \mathrm{L}$ of bis(3,5,5trimethylhexyl)phthalate to protect the assay mixture from air (19). The incubation was carried out at $37^{\circ} \mathrm{C}$ in the dark, and was terminated by adding $400 \mu \mathrm{L}$ of ice-cold water to the incubation mixture. $\left[{ }^{14} \mathrm{C}\right]$ Methionine was quantitated as described (15).

Hcy and methionine in the culture medium were assayed with HPLC methods based on precolumn derivatization with 7-flu- 
oro-benzo-2-oxa-1,3-diazole-4-sulfonate (Hcy) or 0 -phthaldialdehyde (methionine) and fluorescence detection (15).

Protein was determined by the method of Bradford (20) using bovine $\gamma$-globulin as standard.

Curve fitting and calculation of export rates. The logarithm of the cell number $(N)$ and the logarithm of the amount of Hcy accumulated in the medium $(y)$ were plotted versus time of incubation, and the curves were fitted to polynomial functions. The Hcy export rate $(v)$, given as the amount of Hcy exported per unit time and cell mass, was calculated from the equation

$$
v=d y / d t / N
$$

The export rates were plotted against cell density.

Details on the curve fitting and construction of export rate curves have been published $(11,17)$.

Statistical analysis. The effect of nitrous oxide on methionine synthase activity in mutant cells cultured in various concentrations of methionine was evaluated by relating the residual activity to time of exposure, using the Spearman rank correlation coefficient. The $p$ values are given as one-tailed.

\section{RESULTS}

Methionine synthase activity in extract from mutant fibroblasts. Methionine synthase activities were measured in extracts from the mutant cell lines and compared with the activity in normal fibroblasts. Highest activity was found in normal fibroblasts, followed by a moderate reduction in activity in the two cystathionine $\beta$-synthase-deficient cell lines (CSD 751 and CSD 1374 cells) and in the three cobalamin E mutants (cb1E 1384, cblE 788, and cblE 1575), in that order. Lowest activity was observed in extract from the cobalamin G lines (cblG 1308, cblG TA and cblG 2009 cells).

The enzyme activities in the mutant cell lines grown in a culture medium containing $30 \mu \mathrm{mol} / \mathrm{L}$ methionine are summarized in Table 1.

When normal and mutant fibroblasts were transferred to culture media containing variable methionine concentration in the absence of nitrous oxide, moderate changes $(<30 \%)$ in methionine synthase activity was observed throughout the experimental period of $48 \mathrm{~h}$. In most experiments, the activity increased slightly for the first $24 \mathrm{~h}$ and then leveled off. No consistent effect from methionine was observed.

Methionine biosynthesis in intact mutant fibroblasts. Intact cell methionine biosynthesis in cystathionine $\beta$-synthase-deficient cell lines was comparable with that previously observed in control fibroblasts (15), whereas in all the cblG and cblE lines, it was low, i.e. less than $20 \%$ of the activity in the cystathionine $\beta$ synthase-deficient cells (Table 2). Thus, disparity exists between measurements of remethylation in intact cells and in cell extracts.

Nitrous oxide markedly $(>50 \%)$ inhibited the remethylation

Table 1. Methionine synthase activity in normal and mutant fibroblast in air*

\begin{tabular}{lc}
\hline Cell line & $\begin{array}{c}\text { Methionine synthase } \\
\text { activity (nmol/h/mg } \\
\text { protein) }\end{array}$ \\
\hline Control 5659B & $20.8 \pm 2.9$ \\
Control MRC-5 & $24.6 \pm 1.1$ \\
CSD 751 & $19.0 \pm 1.0$ \\
CSD 1374 & $14.0 \pm 1.5$ \\
cb1G TA & $6.7 \pm 1.1$ \\
cb1G 1308 & $3.8 \pm 0.5$ \\
cb1G 2009 & $3.2 \pm 0.5$ \\
cb1E 788 & $13.6 \pm 2.2$ \\
cb1E 1384 & $8.4 \pm 0.6$ \\
cb1E 1575 & $11.9 \pm 2.5$ \\
\hline
\end{tabular}

- Methionine synthase activity was determined in extracts from six parallel samples from each cell line.
Table 2. Effect of nitrous oxide on intact cell methionine biosynthesis in normal and mutant human fibroblasts*

\begin{tabular}{lcc}
\hline & \multicolumn{2}{c}{ Methyl group incorporated } \\
\cline { 2 - 3 } \multicolumn{1}{c}{ Cell line } & $-\mathrm{N}_{2} \mathrm{O}$ (pmol/ & $+\mathrm{N}_{2} \mathrm{O}$ (pmol/ \\
$10^{6}$ cells) & $10^{6}$ cells) \\
\hline Control 5659B & $97.3 \pm 5.0$ & $28.4 \pm 3.2$ \\
Control MRC-5 & $414.0 \pm 64.8$ & $61.6 \pm 18.3$ \\
CSD 751 & $167.0 \pm 15.3$ & $73.3 \pm 4.5$ \\
CSD 1374 & $129.3 \pm 19.3$ & $62.0 \pm 6.9$ \\
cb1G TA & $19.9 \pm 1.8$ & $14.8 \pm 0.9$ \\
cb1G 1308 & $30.5 \pm 11.3$ & $21.6 \pm 5.2$ \\
cb1G 2009 & $4.8 \pm 0.9$ & $4.6 \pm 0.4$ \\
cb1E 788 & $12.8 \pm 0.3$ & $12.7 \pm 0.8$ \\
cb1E 1384 & $7.1 \pm 1.3$ & $7.0 \pm 0.6$ \\
cb1E 1575 & $16.0 \pm 2.5$ & $13.7 \pm 2.4$ \\
\hline
\end{tabular}

* Fibroblasts $\left(2-6 \cdot 10^{5}\right.$ cells $\left./ \mathrm{mL}\right)$ were cultured in the absence and presence of nitrous oxide for $18 \mathrm{~h}$ in a medium containing $\mathrm{N}^{5}$-[methyl$\left.{ }^{14} \mathrm{C}\right]$ methyl-THF and Hcy-thiolactone, as described in Materials and Methods. The incorporation of radioactivity from $\mathrm{N}^{5}-\left[\right.$ methyl $\left.-{ }^{14} \mathrm{C}\right]$ methyl-THF into acid-precipitable material was determined. Values are mean of four determinations $\pm \mathrm{SD}$.

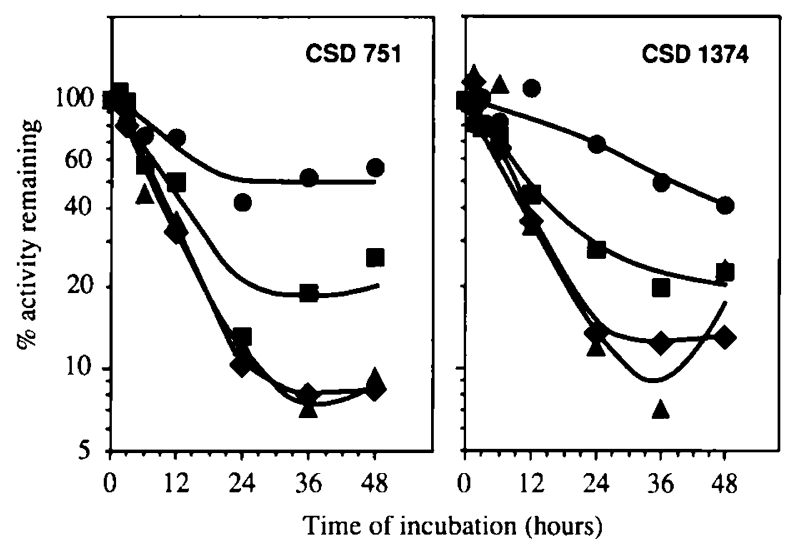

Fig. 2. Methionine synthase inactivation by nitrous oxide in human cystathionine $\beta$-synthase-deficient fibroblasts cultured in the presence of various concentrations of methionine. The CSD 751 cells and CSD 1374 cells were grown to $0.34 \cdot 10^{5}$ cells $/ \mathrm{mL}$ and $0.65 \cdot 10^{5}$ cells $/ \mathrm{mL}$, respectively, and then transferred to a medium containing $15(\$), 30(\Delta), 150$ $(\square)$, and $1000(\bullet) \mu \mathrm{mol} / \mathrm{L}$ methionine. The results are given as percent activity remaining, which is the activity of the cells exposed to nitrous oxide in percent of the activity of control cells. Each value is the average of duplicate measurements. The change in methionine synthase activity versus time was evaluated at each methionine concentration, and there was a significant $(p<0.05)$ decrease in enzyme activity of CSD $751(r$ $=-0.88$ to -0.95$)$ and CSD 1374 cells $(r=-0.64$ to -0.95$)$ at all concentrations.

in intact cystathionine $\beta$-synthase-deficient cells, had a moderate or no effect on the activity in intact cblG cells, and was without effect in cb1E cells (Table 2).

Inactivation of methionine synthase in mutant fibroblasts by nitrous oxide. The inactivation of methionine synthase by nitrous oxide was investigated in mutant fibroblasts cultured in the presence of 15 to $1000 \mu \mathrm{mol} / \mathrm{L}$ methionine.

In cystathionine $\beta$-synthase-deficient cell lines, methionine synthase was rapidly and extensively inactivated. The inactivation was more pronounced at low compared with high concentrations of methionine in the medium (Fig. 2).

In cblG cells, methionine synthase was moderately $(<66 \%)$, but significantly $(p<0.05)$ reduced following nitrous oxide exposure. The inactivation was independent of the methionine concentration in the medium (Fig. 3).

In cblE cells exposed to nitrous oxide, the variability in methionine synthase was somewhat larger than that observed for 


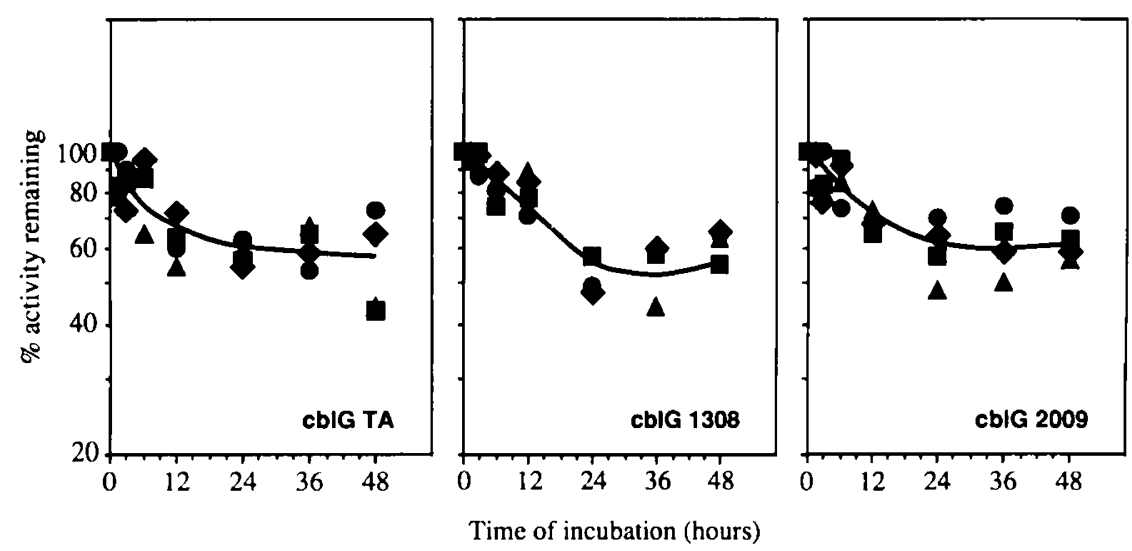

Fig. 3. Methionine synthase inactivation by nitrous oxide in human cobalamin $G$ mutant fibroblasts cultured in the presence of various concentrations of methionine. The cell densities of the cb1G TA cells, cblG 1308 cells and cb1G 2009 cells at the start of the experiment were 0.53 . $10^{5}$ cells $/ \mathrm{mL}, 0.91 \cdot 10^{5}$ cells $/ \mathrm{mL}$, and $0.85 \cdot 10^{5}$ cells $/ \mathrm{mL}$, respectively. Treatment, presentation of data, and symbols were as described in the legend to Fig. 2 . The change in methionine synthase activity versus time was evaluated at each methionine concentration, and there was a significant $(p<$ 0.05 ) decrease $(r=-0.67$ to -0.95$)$ in activity of all three mutant cell lines at all methionine concentrations.

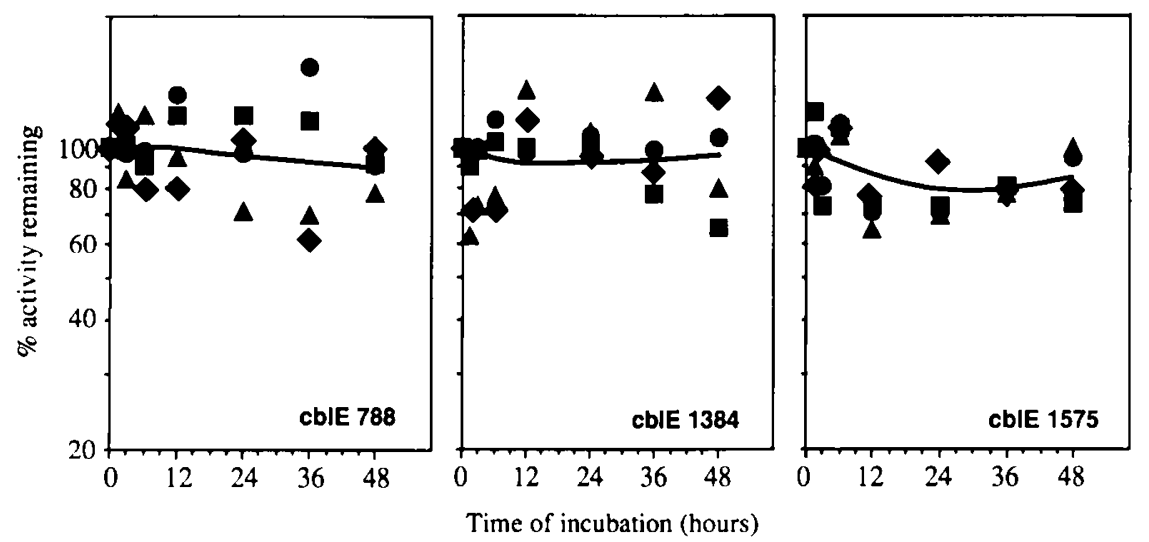

Fig. 4. Methionine synthase inactivation by nitrous oxide in human cobalamin $E$ mutant fibroblasts cultured in the presence of various concentrations of methionine. The cell densities of the cb1E 788 cells, cb1E 1384 cells and cb1E 1575 cells at the start of the experiment were 0.88 . $10^{5}$ cells $/ \mathrm{mL}, 0.43 \cdot 10^{5}$ cells $/ \mathrm{mL}$, and $0.74 \cdot 10^{5}$ cells $/ \mathrm{mL}$, respectively. Treatment, presentation of data, and symbols were as described in the legend to Fig. 2 . The change in methionine synthase activity versus time was evaluated at each methionine concentration. There were no significant $(p>$ $0.05)$ changes $(r=-0.55$ to +0.47$)$ in activities in these cells following nitrous oxide exposure, except for the cb $1 \mathrm{E} 788$ cells cultured in the presence of $30 \mu \mathrm{mol} / \mathrm{L}$ methionine, where a significant decline $(r=-0.76)$ in activity was observed.

control fibroblasts, cystathionine $\beta$-synthase-deficient cells and cb1G cells. However, no decrease in enzyme activity was observed during nitrous oxide exposure (Fig. 4).

Hcy export at different methionine concentrations. The Hcy export rates were investigated in all eight types of mutant fibroblast lines in the presence of 15 to $1000 \mu \mathrm{mol} / \mathrm{L}$ methionine. The experiments were carried out at two different cell densities because the Hcy export rate is related to cell density and growth phase (17). One design (highest cell density) corresponds to the inactivation experiment depicted in Figs. 2-4.

In both cystathionine $\beta$-synthase-deficient cell lines, the Hcy export rate was relatively low at low medium methionine, and increased 2-3-fold upon methionine loading (Fig. 5, Table 3).

Methionine loading only moderately $(15-20 \%)$ increased the Hcy export rate in two of the cblG lines (cblG TA and cblG 2009 cells), and slightly (10\%) in one line (cblG 1308) (Fig. 5, Table 3). The Hcy export from the cobalamin E mutants (cblE

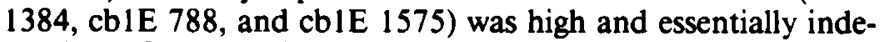
pendent of the methionine concentration (Fig. 5, Table 3).

Export rate curves typical for each cell type are shown in Fig. 5 , and the results for all cell lines are summarized and compared with normal fibroblasts in Table 3 . Table 3 also demonstrates that the same results were obtained at different cell densities.

Hcy export during nitrous oxide exposure at different methionine concentrations. The Hcy export rates were determined for all eight mutant lines exposed to nitrous oxide and cultured in the presence of $15-1000 \mu \mathrm{mol} / \mathrm{L}$ methionine. The experimental design (high and low density) was the same as that of the experiments described in the preceding paragraph.

At low concentrations of methionine in the medium, nitrous oxide increased the Hcy export rate up to or slightly above the rate observed without nitrous oxide and with $1000 \mu \mathrm{mol} / \mathrm{L}$ methionine. The enhancement caused by nitrous oxide was pronounced for cell lines where the Hcy export in the absence of nitrous oxide was highly dependent on methionine, i.e. control fibroblasts, cystathionine $\beta$-synthase-deficient cell lines, and, to a lesser degree, the cblG cells (Fig. 5). Nitrous oxide did not increase Hcy export from the cblE cells (Fig. 5). Thus, in the presence of nitrous oxide, the Hcy export from normal and mutant fibroblasts was high and essentially independent on methionine. The cystathionine $\beta$-synthase-deficient cell lines were exceptions to this general observation, because the export from these cells increased as a function of the methionine concentration also during nitrous oxide exposure (Fig. 5).

Also these data are summarized in Table 3 , and the same results were obtained at different cell densities.

Methionine in the culture medium. We measured the methionine concentration in the culture medium during cell growth. Moderate reduction in methionine $(<20 \%)$ was observed at initial concentrations higher than $30 \mu \mathrm{mol} / \mathrm{L}$. The largest methi- 
Table 3. Effect of methionine loading and nitrous oxide exposure on maximum homocysteine export in normal and mutant human fibroblast $s^{*}$

\begin{tabular}{|c|c|c|c|c|c|c|c|c|c|c|}
\hline \multirow[b]{4}{*}{ Cell line } & \multirow{4}{*}{$\begin{array}{c}\text { Cell density at } \\
\text { start }\left(10^{5}\right. \\
\text { cells } / \mathrm{mL})\end{array}$} & \multirow{4}{*}{$\begin{array}{c}\text { Cell density at } \\
\text { max. export } \\
\left(10^{5} \text { cells } / \mathrm{mL}\right)\end{array}$} & \multicolumn{8}{|c|}{ Methioning concentration } \\
\hline & & & \multicolumn{8}{|c|}{ Homocysteine export rate } \\
\hline & & & \multicolumn{4}{|c|}{$-\mathrm{N}_{2} \mathrm{O}\left(\mathrm{nmol} / \mathrm{h} / 10^{6}\right.$ cells $)$} & \multicolumn{4}{|c|}{$+\mathrm{N}_{2} \mathrm{O}\left(\mathrm{nmol} / \mathrm{h} / 10^{6}\right.$ cells $)$} \\
\hline & & & $15 \mu \mathrm{M}$ & $30 \mu \mathrm{M}$ & $150 \mu \mathrm{M}$ & $1000 \mu \mathrm{M}$ & $15 \mu \mathrm{M}$ & $30 \mu \mathrm{M}$ & $150 \mu \mathrm{M}$ & $1000 \mu \mathrm{M}$ \\
\hline \multirow[t]{2}{*}{ Control 5659B† } & 0.25 & $0.61-0.76$ & 0.12 & 0.13 & 0.23 & 0.68 & 0.68 & 0.72 & 0.71 & 0.82 \\
\hline & 1.05 & $1.06-1.68$ & 0.15 & 0.17 & 0.33 & 0.90 & 0.93 & 0.86 & 0.89 & 1.00 \\
\hline \multirow[t]{2}{*}{ Control MRC-5† } & 0.49 & $0.50-1.00$ & 0.21 & 0.23 & 0.29 & 0.64 & 0.43 & 0.43 & 0.46 & 0.64 \\
\hline & 1.16 & $1.17-1.56$ & 0.18 & 0.19 & 0.38 & 0.72 & 0.74 & 0.71 & 0.72 & 0.74 \\
\hline \multirow[t]{2}{*}{ CSD 751} & 0.08 & $0.08-0.09$ & 0.55 & 0.57 & 0.62 & 0.91 & 0.69 & 0.79 & 0.78 & 0.97 \\
\hline & 0.34 & $0.34-0.41$ & 0.27 & 0.36 & 0.42 & 0.81 & 0.61 & 0.57 & 0.72 & 0.79 \\
\hline \multirow[t]{2}{*}{ CSD 1374} & 0.08 & $0.08-0.10$ & 0.27 & 0.42 & 0.43 & 0.90 & 0.67 & 0.74 & 0.67 & 1.04 \\
\hline & 0.65 & $0.65-0.67$ & 0.19 & 0.23 & 0.38 & 0.68 & 0.37 & 0.40 & 0.49 & 0.82 \\
\hline \multirow[t]{2}{*}{ cblGTA } & 0.46 & $0.61-0.64$ & 0.47 & 0.50 & 0.52 & 0.60 & 0.68 & 0.70 & 0.67 & 0.67 \\
\hline & 0.53 & $0.59-0.62$ & 0.65 & 0.64 & 0.65 & 0.84 & 0.89 & 0.86 & 0.83 & 0.87 \\
\hline \multirow[t]{2}{*}{ cblG 1308} & 0.27 & $0.41-0.50$ & 0.81 & 0.96 & 0.81 & 0.87 & 0.92 & 1.05 & 0.87 & 0.86 \\
\hline & 0.91 & $1.01-1.04$ & 0.50 & 0.49 & 0.46 & 0.55 & 0.53 & 0.55 & 0.54 & 0.56 \\
\hline \multirow[t]{2}{*}{ cblG 2009} & 0.30 & $0.45-0.72$ & 0.73 & 0.74 & 0.63 & 0.82 & 0.87 & 0.87 & 0.92 & 0.92 \\
\hline & 0.85 & $0.93-1.13$ & 0.35 & 0.35 & 0.35 & 0.50 & 0.48 & 0.48 & 0.44 & 0.56 \\
\hline \multirow[t]{2}{*}{ cblE 788} & 0.11 & $0.27-0.28$ & 1.60 & 1.49 & 1.61 & 1.61 & 1.91 & 1.77 & 1.52 & 1.65 \\
\hline & 0.88 & $0.98-1.17$ & 0.79 & 0.79 & 0.84 & 0.86 & 0.80 & 0.71 & 0.72 & 0.79 \\
\hline \multirow[t]{2}{*}{ cblE 1384} & 0.19 & $0.30-0.34$ & 0.97 & 0.92 & 0.91 & 0.96 & 0.92 & 0.88 & 0.96 & 0.95 \\
\hline & 0.43 & $0.43-0.51$ & 1.01 & 1.15 & 1.15 & 1.17 & 1.07 & 1.19 & 1.19 & 1.12 \\
\hline \multirow[t]{2}{*}{ cblE 1575} & 0.17 & $0.42-0.44$ & 1.07 & 1.04 & 1.04 & 1.26 & 1.14 & 1.14 & 1.14 & 1.29 \\
\hline & 0.74 & $1.01-1.04$ & 0.85 & 0.86 & 0.95 & 0.94 & 0.75 & 0.97 & 1.00 & 0.96 \\
\hline
\end{tabular}

* Experiments with each cell line were performed at low (first line) and high (second line) cell density.

† Data from ref. 15.

onine consumption was observed with CSD 1374 cells (about $40 \%$ ) and the cblG 2009 cells (about $70 \%$ ) grown at $15 \mu \mathrm{mol} / \mathrm{L}$ for $6 \mathrm{~d}$ (data not shown).

\section{DISCUSSION}

Experimental design and parameters investigated. Isolated or cultured cells are useful to investigate the interaction of nitrous oxide with methionine synthase because metabolite concentrations affecting the susceptibility of the intracellular enzyme may be controlled by varying the composition of the culture medium $(13,15)$.

We determined three parameters that reflect the functional state of methionine synthase, i.e. intact cell methionine biosynthesis, methionine synthase activity in cell extract, and Hcy export rate.

Intact cell methionine biosynthesis is a measure of metabolic flux through the methionine synthase in cells incubated with high concentration of homocysteine without methionine. This technique demonstrates catalytic activity of the enzyme localized in its intracellular environment, allows the evaluation of nitrous oxide induced enzyme inactivation, but cannot be performed in the presence of various concentrations of methionine.

Measurement of methionine synthase in cell free extract determines enzyme activity in a constructed medium containing reducing agent(s), and supraphysiological concentrations of homocysteine, 5-methyl-THF and $S$-adenosylmethionine (21). The activity can be determined in extract from cells exposed for various time periods to nitrous oxide and methionine, and this allows the assessment of the kinetics of inactivation. However, methionine synthase activity in extract does not necessarily reflect the activity in intact cells, as demonstrated for the cblE mutant (22).

Hcy export rate reflects an imbalance between Hcy production and metabolism in intact cells (2). Conceivably, the process is affected by the activities of various enzymes, including methionine synthase. Sampling from the culture medium is convenient, and detailed kinetic studies can be performed with cells exposed to various agents, including nitrous oxide and methionine (13, 15).

Inactivation of methionine synthase by nitrous oxide in normal intact cells. We have recently demonstrated that the inactivation of methionine synthase by nitrous oxide in normal human fibroblasts cultured in defined media is enhanced by high folate content (13) or by low levels of methionine (15). Low folate and high methionine in the culture medium probably protect methionine synthase against inactivation by reducing the catalytic turnover. Methionine may act through product inhibition, whereas low folate may reduce the availability of the cosubstrate, 5 -methyl-THF $(13,15)$. This explanation is supported by data on isolated methionine synthase showing that the enzyme inactivation by nitrous oxide is dependent on catalytic turnover, and occurs only in the presence of all components required for enzyme catalysis (23).

In normal fibroblasts, nitrous oxide rapidly inactivated methionine synthase and markedly increased the Hcy export rate at low medium methionine, so that in exposed cells, the export is high and independent on the concentration of methionine in the medium (Table 3) (15).

Effect of nitrous oxide and methionine loading in mutant fibroblasts. At low medium methionine, methionine synthase was rapidly inactivated by nitrous oxide in the cystathionine $\beta$ synthase-deficient fibroblasts (Fig. 2), and this agrees with marked enhancement of Hcy export (Fig. 5, Table 3). At high methionine, the enzyme is partly protected against inactivation by nitrous oxide (Fig. 2), which under these conditions did not enhance the Hcy export (Fig. 5, Table 3). The methionine loading effect on Hcy export, visualized as a dose-dependent increase in export rate when methionine concentration is increased from 15 to $1000 \mu \mathrm{mol} / \mathrm{L}$, is partly abrogated during nitrous oxide exposure (Fig. 5, Table 3). Thus, the response of cystathionine $\beta$ synthase-deficient fibroblasts to nitrous oxide exposure at various methionine concentrations resembles that observed with the normal fibroblasts (15), except that a certain methionine loading effect remained even in the presence of nitrous oxide. This finding suggests that cystathionine $\beta$-synthase in normal cells 

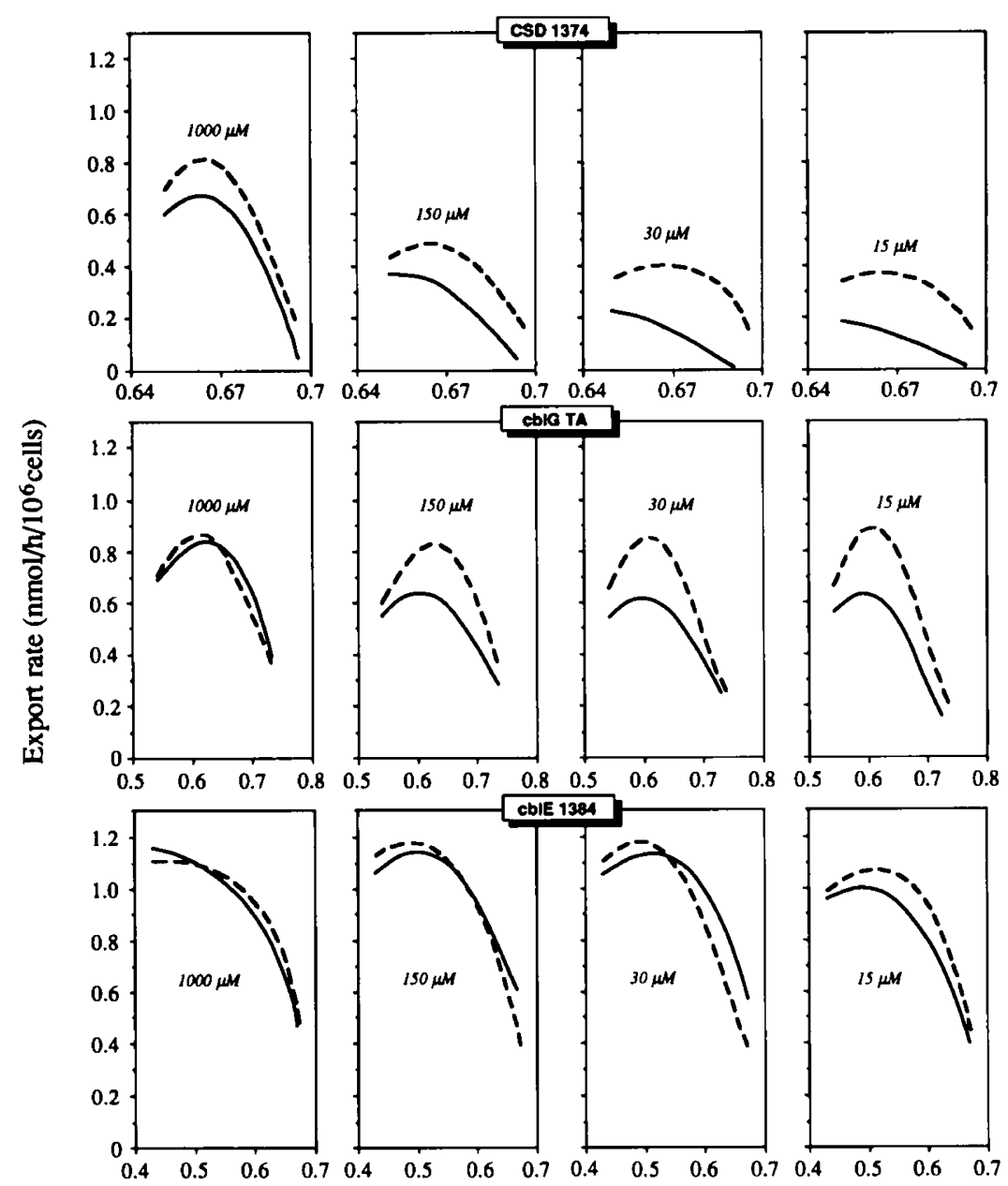

\section{Cell density $\left(10^{5}\right.$ cells/ml $)$}

Fig. 5. The effect of nitrous oxide on Hcy export from three mutant fibroblasts cell lines cultured in the presence of various concentrations of methionine. The concentrations of methionine $(15-1000 \mu \mathrm{mol} / \mathrm{L})$ are indicated on the graph. The cells were cultured for $48 \mathrm{~h}$. Results from cells exposed to air are given as solid lines, and from cells exposed to nitrous oxide as broken lines.

limits the amount of Hcy exported at high methionine levels.

Methionine synthase in the cblG mutants was only slightly inactivated by nitrous oxide, and the inactivation process was not modulated by the methionine concentration in the medium (Fig. 3). The moderate inactivation may be explained by the slow catalytic turnover of this enzyme, as indicated by the low intact cell methionine biosynthesis in these cells (Table 2) and the moderate increase in Hcy export rate following nitrous oxide exposure (Fig. 5, Table 3). Lack of protection may reflect altered regulatory properties of the mutant methionine synthase. The observation that $\mathrm{cb} 1 \mathrm{G}$ mutant methionine synthase has altered in vivo response to $S$-adenosylmethionine compared with normal enzyme (24) may reflect such properties.

Methionine synthase in the cblE mutants was not inactivated by nitrous oxide (Fig. 4) and there was no effect of nitrous oxide on the Hcy export rate (Fig. 5, Table 3). This observation agrees with published results $(22)$ and may be related to the slow catalytic turnover of the intracellular enzyme as demonstrated by the low intact cell remethylation (Table 2) (22).

Role of methionine synthase in Hcy metabolism and export. Hcy in mammalian cells is distributed between three competing routes of disposal: remethylation, which in non-liver tissues is catalyzed by methionine synthase, catabolism by cystathionine $\beta$-synthase (1), and release of Hcy into the extracellular medium (2).

The present results with mutant (cblG and cblE) cells with defective methionine synthase (Fig. 5, Table 3 ) perfectly agree with those obtained with normal cells where methionine synthase was inactivated with nitrous oxide (15). Cells with inhibited methionine synthase have a high Hcy export at low extracellular levels of methionine, and the export is not or only slightly dependent on methionine level. This adds support to the hypothesis that methionine synthase has a major impact on Hcy export at physiologic methionine concentrations, and agrees with methionine synthase as a low $K_{m}$ and methionine-conserving enzyme (1). It also suggests that methionine synthase activity has a major impact on fasting plasma Hcy level. Notably, fasting levels are high in subjects with impaired methionine synthase due to folate or cobalamin deficiency $(25-28)$, and there are clinical observations (8) indicating that such patients have a normal response to methionine loading.

An abnormal methionine loading test, on the other hand, is observed in heterozygotes (29) or homozygotes (6) for cystathionine $\beta$-synthase deficiency. This clinical observation is a corollary to the results obtained with the cystathionine $\beta$-synthasedeficient fibroblasts (Fig. 5, Table 3), showing enhanced Hcy export when the methionine concentration is increased above the physiologic level, even under conditions when methionine synthase is inhibited by nitrous oxide. Thus, an abnormal methionine loading test may reflect the amount of Hcy that escape catabolism when methionine synthase is saturated.

Comparison of the functional state of methionine synthase in cblG and cblE mutants. Both cblG and cblE cells accumulate normal amounts of cobalamin, but there is decreased synthesis 
of methylcobalamin (26). In both classes, intact cell methionine biosynthesis as determined by incorporation of label from 5$\left[{ }^{14} \mathrm{C}\right]$ methyl-THF into acid-precipitable material, is low (26) (Table 2). The properties of methionine synthase in cblG and cblE mutants are different. In extract from cblE mutants, normal activity was found in the standard assay including a reductant and cobalamin, whereas the activity in extract from cblG mutants was low under these conditions (26) (Table 2). The sites of defects has not been identified. An increased requirement for a reductant by the cblE enzyme suggests that the mutation in cblE affects a reducing system necessary to keep enzyme-bound cobalamin in its reduced form. The defect in cb/G mutants is probably localised to methionine synthase itself (30).

The present data further distinguish the functional state of methionine synthase cblG and cblE mutants. CblE cells cultured in the presence of high levels of Hcy show low intact methionine biosynthesis (Table 2). However, in standard culture medium, the methionine synthase in intact cb1E cells is probably catalytically inactive. This conclusion is supported by the high Hcy export which is not influenced by methionine concentration or nitrous oxide (Fig. 5, Table 3), and lack of nitrous oxideinduced inactivation of the enzyme activity measured in cell free extract (Fig. 4). Methionine synthase in intact cb1G cells, on the other hand, seems to have low catalytic activity, as judged by low intact cells methionine biosynthesis (Table 2), slight enhancement of Hcy export by nitrous oxide at low methionine level (Fig. 5, Table 3), and moderate inactivation of the enzyme by nitrous oxide (Fig. 3).

\section{SUMMARY AND CONCLUSION}

Low catalytic turnover of methionine synthase caused by low substrate availability (13), high concentration of the product methionine (15), or by different mutations is associated with reduced susceptibility of the enzyme to nitrous oxide induced inactivation.

Cells with intact methionine synthase have low Hcy export at low concentration of methionine. Such cells respond to excess methionine by a marked increase in the Hcy export rate. Functional methionine synthase deficiency due to genetic mutations or pharmacologic inhibition abrogates the methionine loading effect. These cells show a high Hcy export rate that is independent of methionine and probably limited by Hcy catabolism via cystathionine $\beta$-synthase.

Mutant fibroblasts of the complementation classes cb $1 \mathrm{G}$ and $\mathrm{cblE}$ have defects in methionine synthase, and the present study adds to the data suggesting functional diversity of methionine synthase in these mutants.

Acknowledgments. The authors thank E. Gundersen, H. Bergesen, and G. Kvalheim for technical assistance.

\section{REFERENCES}

1. Finkelstein JD 1990 Methionine metabolism in mammals. J Nutr Biochem 1:228-237

2. Ueland PM, Refsum H 1989 Plasma homocysteine, a risk factor for vascular disease: plasma levels in health, disease, and drug therapy. J Lab Clin Med 114:473-501

3. Kang S-S, Wong PWK, Malinow MR 1992 Hyperhomocsyt(e)inemia as a risk factor for occlusive vascular disease. Annu Rev Nutr 12:279-298

4. Ueland PM, Refsum H, Brattström L 1992 Plasma homocysteine and cardiovascular disease. In: Francis Jr RB (ed) Atherosclerotic Cardiovascular Disease, Hemostasis, and Endothelial Function. Marcel Dekker, Inc, New York, pp $183-236$

5. Ueland PM, Refsum H, Stabler SP, Malinow MR, Andersson A, Allen RH 1993 Total homocysteine in plasma or serum: methods and clinical applications. Clin Chem 39:1764-1779
6. Mudd SH, Levy HL, Skovby F 1989 Disorders of transsulfuration. In: Scriver CR, Beaudet AL, Sly WS, Valle D (eds) The Metabolic Basis of Inherited Disease. McGraw-Hill, New York, pp 693-734

7. Cooper BA, Rosenblatt DS 1987 Inherited defects of vitamin B12 metabolism. Annu Rev Nutr 7:291-320

8. Brattström L, Israelsson B, Norrving B, Bergqvist D, Thöme J, Hultberg B Hamfelt A 1990 Impaired homocysteine metabolism in early-onset cerebral and peripheral occlusive arterial disease: effects of pyridoxine and folic acid treatment. Atherosclerosis $81: 51-60$

9. Refsum H, Ueland PM, Kvinnsland S 1986 Acute and long-term effects of high-dose methotrexate treatment on homocysteine in plasma and urine. Cancer Res 46:5385-5391

10. Refsum H, Wesenberg F, Ueland PM 1991 Plasma homocysteine in children with acute lymphoblastic leukemia. Changes during a chemotherapeutic regimen including methotrexate. Cancer Res 51:828-835

11. Refsum H, Christensen B, Djurhuus R, Ueland PM 1991 Interaction between methotrexate, "rescue" agents and cell proliferation as modulators of homocysteine export from cells in culture. J Pharmacol Exp Ther 258:559-566

12. Ermens AAM, Refsum H, Rupreht J, Spijkers LJM, Guttormsen AB, Lindemans J, Ueland PM, Abels J 1991 Monitoring cobalamin inactivation during nitrous oxide anesthesia by determination of homocysteine and folate in plasma and urine. Clin Pharmacol Ther 49:385-393

13. Christensen B, Refsum H, Garras A, Ueland PM 1992 Homocysteine remethylation during nitrous oxide exposure of cells cultured in media containing various concentrations of folates. J Pharmacol Exp Ther 261:10961105

14. Banks RGS, Henderson RJ, Pratt JM 1968 Reactions of gases in solution. Part III. Some reactions of nitrous oxide with transition-metal complexes. J Chem Soc (A):2886-2889

15. Christensen B, Ueland PM 1993 Methionine synthase inactivation by nitrous oxide during methionine loading of normal human fibroblasts: homocysteine remethylation as determinant of enzyme inactivation and homocysteine export. J Pharmacol Exp Ther (in press)

16. Shuch S, Rosenblatt DS, Cooper BA, Schroeder M-L, Bishop AJ, Seargeant LE, Haworth JC 1984 Homocystinuria and megaloblastic anemia responsive to vitamin B12 therapy: an inborn error of metabolism due to defect in cobalamin metabolism. N Engl J Med 310:686-690

17. Christensen B, Refsum H, Vintermyr O, Ueland PM 1991 Homocysteine export from cells cultured in the presence of physiological or superfluous levels of methionine: methionine loading of non-transformed, transformed, proliferating and quiescent cells in culture. J Cell Physiol 146:52-62

18. Weissbach H, Peterkofsky A, Redfield BG, Dickermann H 1963 Studies on the terminal reaction in the biosynthesis of methionine. J Biol Chem 238:3318-3324

19. Garras A, Djurhuus R, Christensen B, Lillehaug JR, Ueland PM 1991 A nonradioactive assay for N5-methyltetrahydrofolate-homocysteine methyitransferase (methionine synthase) based on o-phthaldialdehyde derivatization of methionine and fluorescence detection. Anal Biochem 199:112-118

20. Bradford M 1976 A rapid and sensitive method for the quantitation of microgram quantities of protein utilizing the principle of protein-dye binding. Anal Biochem 72:248-254

21. Taylor RT 1982 B12-dependent methionine biosynthesis. In Dolphin D (ed) B12 Vol. 2: Biochemistry and Medicine. John Wiley and Sons, New York, pp 307-355.

22. Rosenblatt DS, Cooper BA, Potter A, Lue-Shing H, Matiaszuk N, Grauer K 1984 Altered vitamin B12 metabolism in fibroblasts from a patient with megaloblastic anemia and homocystinuria due to a new defect in methionine biosynthesis. J Clin Invest 74:2149-2156

23. Frasca V, Riazzi BS, Matthews RG 1986 In vitro inactivation of methionine synthase by nitrous oxide. J Biol Chem 261:15823-15827

24. Hall CA, Lindenbaum RH, Arenson E, Begley JA, Chu RC 1989 The nature of the defect in cobalamin G mutation. Clin Invest Med 12:262-269

25. Kang S-S, Wong PWK, Norusis M 1987 Homocysteinemia due to folate deficiency. Metabolism 36:458-462

26. Stabler SP, Marcell PD, Podell ER, Allen RH, Savage DG, Lindenbaum J 1988 Elevation of total homocysteine in the serum of patients with cobalamin or folate deficiency detected by capillary gas chromatography-mass spectrometry. J Clin Invest 81:466-474

27. Brattström L, Israelsson B, Lindgärde F, Hultberg B 1988 Higher total plasma homocysteine in vitamin B12 deficiency than in heterozygosity for homocystinuria due to cystathionine $\beta$-synthase deficiency. Metabolism 37:175178.

28. Allen RH, Stabler SP, Savage DG, Lindenbaum J 1990 Diagnosis of cobalamin deficiency. 1. Usefulness of serum methylmalonic acid and total homocysteine concentrations. Am J Hematol 34:90-98

29. McGill JJ, Mettler G, Rosenblatt DS, Scriver CR 1990 Detection of heterozygotes for recessive alleles. Homocyst(e)inemia: paradigm of pitfalls in phenotypes. Am J Med Genet 36:45-52

30. Watkins $D$, Rosenblatt DS 1989 Functional methionine synthase deficiency (cb/E and cb/G): clinical and biochemical heterogeneity. Am J Med Genet $34: 427-434$ 